\title{
INDIAN (CONTEXTUAL) READING OF THE BIBLE: AN ALTERNATIVE EXEGETICAL MODEL FOR INDIA
}

\author{
Jijo James Indiparambil \\ Sanjo College of Management and Advanced Studies (SCMAS) \\ Rajakkad, Kerala, India
}

\begin{abstract}
The recent trends in interpretation of the Bible in the West as well as in the East prioritize the Contextual Bible Reading, based on asking questions about one context (contextual questions) and the biblical text (textual questions) with the help of systematic and structured Biblical scholarship. This will link the past with the present (reading behind, on, and in front of the text). The deep-rooted religious traditions (pluri-religious \& cosmocentric) and the socio-economic anomalies (poverty) and issues in India mark a distinct cultural and contextual situation to read the Bible differently. This paper looks for more contextual and experiential reading and understanding of the Sacred Texts which is very much pierced in people's everyday life situations in India. Much of what is discussed in this article will make more sense when persons actually participate in or facilitate a contextual Bible reading focusing on the reality of the local community.
\end{abstract}

Keywords: Biblical exegesis, experiential reading, reader meaning, anicomic monotheism, dynamic monotheism, pluri-religious, cosmocentric.

\section{INTRODUCTION}

The globalized world, in which we make our lives today, is characterized by great socioeconomic, political, cultural and religious diversity along with all its technological affluences. The deep-rooted concern of the church to engage with all people of these multifaceted realities is well explained in the Pastoral Constitution on the "Church in the Modern World," Gaudium et Spes, no. 4, where we read that "at all times the church carries out the task duty of scrutinizing the signs of the times and interpreting them in the light of the gospel. It also urges us to recognize and understand the world in which we live, its explanations, its longings, and its characteristics" (GS 4). Coming to the multifaceted climate of the linguistic, socio-cultural, and religious reality of India, today the traditional form of exegesis to understand the Bible marks no 
International Journal of Arts and Humanities

ISSN: 2581-3102

Volume: 04, Issue: 04 "April 2020"

responds from the people. People look for more contextual and experiential reading and understanding of the Sacred Texts which is very much pierced in their everyday life situations.

Hence, the determined exegetical methods followed generally in other parts of the world, as I evaluate from my experience, cannot be practiced adequately and blindfolded in Indian soil. We need to consider on the one hand, as I strongly believe, the deep-rooted religious traditions of India and the socio-economic anomalies and issues like poverty on the other hand. Therefore, in India, we need to have an 'Indian reading' of the Bible, which is and must be more contextual and experiential. I wish to analyse this 'Indian reading' of the biblical text, in special reference to Isa 44:9-20 that speaks about the idol worship, since Indian religious traditions have a lot of 'idol worships,' as we call it, and other ritual practices connected to it.

\section{WHY AN INDIAN READING?}

Due to the advancement of the multiple ways of reading the Bible with its historical critical method, readers- response approach, and other contextual readings, the doors of new interpretation are widely opened. The "one dimensional hermeneutics, which assumed that the text of the bible has only one true meaning, wholly independent of the class or cultural conditioning of the reader" (Soares-Prabhu 1999, 207), is no more the understanding now. In reader-response criticism, which plays the key role in our discussion, "the focus moved away from thinking of a work as self-contained aesthetic object to considering the experience that transpires when the reader and the work come together" (Dobie 2002, 129).

Here, "the interpretation of meaning is assumed to be an act of reading, thereby making the ultimate authority not the writer or the text but the reader, [...] and this criticism calls for introspection and reflection on one's own values and beliefs, which can lead the reader to deeper personal knowledge and greater cultural awareness" (Dobie 2002, 131). Many are of the opinion that, today, the historical critical method is not really adequate for the study of Bible which is not a scientific text, but a religious text that aims not to convey historical information but to evoke a religious response (D'Sa 1999). Hence, when we interpret the Bible, as we construct the reality, our existing social location, both static and dynamic cultural context, and practicing religious traditions of the place are very important. In this respect, what we need is a self-conscious reading of a Biblical text basing into multifaceted aspects.

In Indian context, historical critical method which tries to dig more to reach the original meaning of the text is criticised because of its ineffectiveness and inability to arrive at conclusive results. When we say an 'Indian context' or 'Indian situation,' we need to understand that India, on the one hand, is emerging as one of the fast developing countries and is well known for its concern of pluriform religiosity that India tolerates, and on the other hand, which I feel as the saddest 
International Journal of Arts and Humanities

ISSN: 2581-3102

Volume: 04, Issue: 04 "April 2020"

side, we have the massive poverty (fifty per cent of its total population still lives below the defined 'poverty line') and then the oppressive and all-pervasive social structure of castes and classes.

The problem persisting is that, as it is argued from various parts, on the one hand, its efforts seem to have left us with a ruinous heap of hypothetical possibilities, and on the other hand, it seems incapable of ever reaching any universally accepted conclusions, because the results achieved now will be challenged tomorrow's context (Padinjarekuttu 1999). This method has also been criticised for its remote intelligibility to the ordinary people, because it brackets off the concrete personal and social concerns and problems that really matter to people. Another problem related to this, according to George Soares Prabhu, is that "the problem of irrelevance is accentuated in India where biblical exegesis is done almost exclusively in seminaries and Church faculties, where academic irrelevance is compounded by cultural isolation" (Padinjarekuttu 1999, 212). George Soares-Prabhu, an Indian Jesuit priest, was well known Exegete and Biblical scholar, especially in the field of Indian Hermeneutics of the Christian Scriptures. He was an ardent advocate of a Liberation Theology adapted to the Indian ethos and socio-religious context, and thus, an impassioned spokesman of contextual theologies in India. He tried to articulate an Indian Christian Theology in all his works as a professor and a theologian. For him, "to do theology means to contextualize one's faith" (Soares-Prabhu 1991, 55).

He also fears that the western theology and "western style exegesis elaborated in and designed for the consumer capitalist society of the affluent West, is thrust down the throats of bewildered Third World people living among starving, oppressed, largely non-Christian masses - whose concerns seldom figured in our theological texts" (Padinjarekuttu 1999, 212) and analysis. Moreover, the single-minded concern of the historical critical method for recovering the possible original meaning of the author and text, often fails to see and speak to the contemporary needs of the people. This inadequacies actually calls for an alternative method, in disenchantment with Historical Criticism, to make bible relevant for the needs and concerns of the people, and it is, all the more, an essential task to the Indian theologians who are in contact with people with multi faceted social and cultural fabrications.

Moreover, the relevance of Indian exegesis is also linked to the traditional Indian theology that studies the sacred books not as an academic exercise but with a practical question for liberation. George Soares-Prabhu explains the problem perceived that, since historical critical method, which was developed as part of the great intellectual revolution of sixteenth and seventeenth century, was the so called standard method of biblical interpretation and same everywhere, no one could think of developing another method to interpret the text. The cultural variations might determine the application of an interpreted text to a given situation, not the interpretation itself. 
International Journal of Arts and Humanities

ISSN: 2581-3102

Volume: 04, Issue: 04 "April 2020"

But, today, in this 'post-modern' world, a growing awareness challenges the neutrality of this method, and now, since the Bible is not a scientific work to communicate the historical information, but to evoke religious response in the people, it looks for more diverse interpretation which is more contextual and experiential (Soares-Prabhu 1999a). The relevance also depends upon the two major elements of the reality of India today - the religious and the social - the wealth of Indian religious traditions or the desperate economic poverty of its people (Padinjarekuttu 1999). For me, it should be the main focus of any theological queries in India.

\subsection{An Alternative Model for India}

The local preferences given in various methods of interpreting the bible, in fact, interact with each other very dynamically and entered into the universe of biblical exegesis. But for George Soares Prabhu, "an Indian exegesis cannot be an exotic plant growing in isolation out of the humid soil of traditional Indian methods of interpretation. Rather it will result from the cross fertilization of modern methods of biblical exegesis with contributions from Indian exegetical tradition, coming to flower in the stormy climate of the socio-cultural reality of India today" (Padinjarekuttu 1999, 215-216). This new approach of the contextualized ways shift attention from the author to the text and to the reader. We see here a movement from 'author meaning' to 'text meaning' and to 'reader meaning'. This reader meaning could be the solid expression of the ordinary experiences that can be actualized in different ways (D'Sa 1999). In fact, it communicates new meaning to new readers in new situations. Moreover, we cannot deny that the text like Bible has 'surplus meaning' (Ricoeur 1976). Surplus meaning is the capacity of the text to communicate new meaning in new situations well beyond what the author may have intended to say. The surplus meaning of the text is actualized by its readers, who bring his/her particular perspective and concern to the text. In this respect, an Indian reading of the bible is very much sensitive to the Indian situation and true to the biblical text. In other words, as George Soares Prabhu would say, "It will be a true-to-the-text reading made with an Indian pre-understanding and responsive to Indian situations" (D'Sa 1999, 5). Therefore, Indian (Christian) reading of the bible cannot dispense fully with historical critical method, but gives further with it surplus meaning.

\subsection{The Specifics of Indian Reading}

Reading Bible in a particular context may mean different things. Fiorenza, in this regard would argue that, "one's social location or rhetorical context is decisive of how one sees the world, constructs reality or interprets biblical texts" (Fiorenza 1988, 5). Here, reading in Indian context would mean that (Soares-Prabhu 1999b):

(1) Interpret the text using traditional Indian methods of interpretation 
International Journal of Arts and Humanities

ISSN: 2581-3102

Volume: 04, Issue: 04 "April 2020"

(2) Read the bible in the light of specifically Indian social concern

(3) Reacting to the bible with an Indian mind (with the sensibilities proper to the Indian mind)

George Soares Prabhu analyses or attempts to have an Indian reading of Is. 44: 9-20 by using this third method. But, here, one may ask the speciality of Indian mind, which needs further explanation. Indian mind is always contextual and context sensitive, and, unlike western style of thinking, it avoids abstract ideas. It is more cosmocentric (which is more holistic and inclusive), than western approach of anthropocentric, in its orientation. The Indian mind always tries to grasp the whole, because things have meaning only as parts of the whole. It is also tolerant of ambiguity and is able to hold together seemingly contradicting aspects of reality as complementary parts (Soares-Prabhu 1999b). In this way, the radical monism of India has its diverse in its radical polytheism.

Reflecting in this line, we see that, in India, the cosmocentric and visual mind of India which is more interested in 'seeing the divine image' than in 'hearing the divine word' has developed a radically polytheistic consciousness that offers a complementary alternative to the biblical myth of anicomic monotheism that has so largely determined habits of thinking in the west (Eck 1985).

\section{AN INDIAN READING OF IS. 44:9-20}

In Is 44: 9-20, we see a strong critique of idolatry mentioned in the Bible. There we read that "all who make idols are nothing, and the things they delight in do no profit; their witnesses neither see nor know. And so they will be put to shame. Who would fashion a god or cast an image that can do no good? Look, all its devotees shall be put to shame; the artisans too are merely human. Let them all assemble, let them stand up; they shall be terrified, they shall all be put to shame..." (Is. 44: 9-20). On the contrary, if we analyse Indian situation, "idol worship" is a normal and edifying religious practice, and idols worshipped are recognized as visual theologies of great depth and power (Soares-Prabhu 1999b). In this respect, an Indian reader who reads Is 44 may become scandalized by this text that offers what seems to be a dishonest caricature of a meaningful religious practice in Indian context. Nevertheless, this uneasiness in an Indian reader must not prevent the reader form listening to the text. This is the tension foreseen here. Therefore, "a responsible Indian reading, which wants to respect both the utterance of the text and the pre-understanding of the reader, must include, then, a critical moment, without which the reading will dissolve into mere subjective reaction" (Soares-Prabhu 1999b, 276). In this situation, George Soares-Prabhu begins the reading of Is 44: 9-20 with a critical reading of the text, which is more theological that tries to find out the overall meaning of the text, and then 
International Journal of Arts and Humanities

ISSN: 2581-3102

Volume: 04, Issue: 04 "April 2020"

reacts to it in an Indian point of view. First we analyse the context and structure of the text, and then the meaning that this text says to a reader in India today.

\subsection{The Context and Structure of Is. 44:9-20.}

This passage is part of Second Isaiah composed during the exile. During the exile, Second Isaiah encouraged his people to have faith in Yahweh's eternal and creative power, and asserted that Yahweh would re-create Israel out of the chaos of the exile (Is 40; 45; 48:12-21). Yahweh's power was seen as universal. The new exodus (liberation / returning from Babylon to Jerusalem) would represent a triumph over the pagan deities, who could not prevent it because in fact they were nonentities; there were no divine realities behind their images (Is 41: 24; 46:1-2, 6-7). This was fully developed monotheism. Explicit and dynamic monotheism is nowhere more vigorously stated. It is expressed in Is 44:6 "I am the first and I am the last; there is no God but me." The exclusive worship of Yahweh is emphasised. Here we also see a shift that, as Bernhard Land would assert, the "polytheistic Israel is dead and out of its ashes arises monotheistic Judaism" (Land 1983, 41). For them, it is the unique power and might of the One God is the guarantee of the return. Here, the Israel is exhorted to return to the only God who has redeemed it (Is 44:21), which will, in fact, causes for their redemption. In this respect, by affirming the uniqueness of Yahweh, we say that, if Yahweh is the only God, then the idols of the nations must "profit nothing" (Soares-Prabhu 1999b, 279). This strives into monotheism shapes the polemic against idols that we find in this passage.

With regard to the arrangement, though an obvious lack of form is projected, a close observation will give us its structure that it begins with an introductory verse that speaks about the makers of idols, about idols, and the worshippers of the idols (v. 9). Then it speaks about the inabilities of the idol makers who are mere human and unable to meet the challenges (vv. 10-14). It also speaks about the blindness of the idol makers and worshippers (vv.15-19). The concluding verse (v. 20) reminds us about the futile nature of this act of making and worshipping the idols. George Soares-Prabhu gives a clear description that "from the general and dispassionate charges levelled against idol makers with which the satire opens (v. 9) we are led through a close description of how idols are made (vv. 12013) and what the making of idols implies (vv. 14-19a), to the concrete, emotionally charged polemical questions with which the satire ends (vv. 19b-20)" (Soares-Prabhu 1999b, 282). This structural analysis also, in fact, stresses and highlights the absolute uniqueness of Yahweh and the efficacy of His saving power.

\subsection{Reading (Reacting to) Is 44: 9-20 with an Indian Mind}

Idol worshippers are generally accused of worshipping a piece of wood or other materials blindly. According to George Soares-Prabhu, those people are well aware that these idols are and remain wood or other stuff like stone, and still they believe that when an idol is "consecrated", 
International Journal of Arts and Humanities

ISSN: 2581-3102

Volume: 04, Issue: 04 "April 2020"

the "god" comes to "dwell" in it, and then the idol mediates the "real presence" of the divine and thus they bow not to the idol but the god made present in the idol (Soares-Prabhu 1999b). In this sense, as Panikkar would illustrate, the idol worshippers are not trying to transfer the adoration due to God alone to a worldly creature, but adores some object upon which the glory of God is descended, and thus, this particular object becomes a point to ascent toward God (Panikkar 1973). Thus, the sin of idol worshipping in some sense becomes a holy act in the eyes of others (here, in this case, particularly in India) who follow different religious and cultural world views.

The Semitic traditions (Jews, Christian, Islamic) understand the core religious experience in an anthropo-theistic perspective: as human response to the divine self-disclosure. God reveals Himself in history and humans respond to the revelation in personal relationship. In sharp contrast to the Semitic traditions, the Hindu world view presents its religious experience as the awareness of the abiding presence of the Divine Mystery in the Cosmos. Hence it upholds mystical experience, the experience of God within oneself leading to the ultimate union with the Divine. This core experience finds its expression in cosmic symbolism (sun, moon, tree, fire, water, etc.).

In this regard, the anti-idol polemic of Is. 44:9-20 brings great problem to the Indian readers. At the same time, George Soares-Prabhu argues that, "it is not enough to dismiss Is.44:9-20 as a 'rampageous satire', deplore its over-enthusiastic polemic, or justify it by simplistic condemnations of idolatry. It must be recognized for what it is: a damaging and therefore sinful misrepresentation of a people's religion and culture. Such a misrepresentation must be judged either as polemically inspired libel or as a remarkable display of prejudiced ignorance" (SoaresPrabhu 1999b, 284).

He also points out that, Yahweh may be unique since having no material image to represent, but an image does not have to be material in Indian thought, since Indian theology recognizes the mental image as one of the eight kinds of materializations of images of divine. For him, this spirituality belongs to the category of iconolatry, for iconolatry consists in a projection of God in some forms that can be material or mental and visible or invisible (Soares-Prabhu 1999b). Iconolatry is defined as the worship of images or icons. Icon in Greek simply denotes a picture but has now come to be closely associated with religious art. In many orthodox churches, it is used to assist in prayer and worship. For me, an idol is something worshipped as divine under the mistaken belief that it is God, where as an icon is an image that reminds us of God which has a sentimental value within a specific culture and history. Thus, idolatry is worshiping something in place of God, and iconolatry is something that inspires people to worship God. This is the reason why Church permits icons when idolatry is forbidden. 
International Journal of Arts and Humanities

ISSN: 2581-3102

Volume: 04, Issue: 04 "April 2020"

Thus, he further explains that the "anthropocentric biblical thinking leads to a single "jealous" anthropomorphic god, just as cosmocentric thinking leads to proliferation of a multitude of less dangerous because less seductive idols, as pluriform as the cosmos itself" (Soares-Prabhu 1999b, 285). Looking at the difference between the worship of Yahweh, the icon of the God of Israel, and the worship of an idol of Baal, George Soares-Prabhu concludes that "the difference is not merely that the image of one is mental and that of the other material, but is of religious attitudes" (Soares-Prabhu 1999b, 285). For him, both kinds of image, the material and mental, lead to the path of ritual or ethical action (associated with karma-marga in Hinduism), and thus, the ways of salvation.

In Hinduism, salvation means liberation (mukti/moksa) from delusion and from the cycle of rebirth leading to realization of the Absolute. From the early post-Vedic period onwards, three ways (marga) of salvation have been commended for reaching the goal of life: the way of rituals and work (karma marga) through which persons purity their activity and ordain themselves towards the goal of liberation; the way of knowledge (jnana marga) which leads persons to realize their unity and oneness with the Absolute; and the way of devotion (bhakti marga) in which the persons with the help of divine assistance of their personal deity (istadevata) attain their original spiritual purity. Thus karma marga is the first way to salvation in Hinduism (Romus 1995). Therefore, it would be encouraged, particularly in Indian situation, to explain the idols not mere human inventions to replace God, but the expressions of a religious experience and therefore of a revelation to worship God and ultimately to be one with Him. Hence, Is. 44: 920 also could be explained and experienced in terms of attitudes that relate one to God and to God's people.

\subsection{From Exclusive to Inclusive Monotheism}

Finally, we see here in this reading, a movement from a cultural suppression to a cultural altitude. A text, thus, cannot be used as a means to suppress the culture and practices of the place by its interpretation. It also calls us to read beyond the text to see a necessary step from exclusive monotheism to a great inclusive one. God of Israel becomes the God of all people of all time and all places. Because since Yahweh is the only God, besides whom there is no other, then he must be the God not just of Israel but of all other people, including the idol worshippers as well. In this context, quoting Danielou, George Soares-Prabhu (1999b, 286) asks, if there is an all powerful, all-pervading divinity, how can we worship anything that is not Him?

The dogmatic constitution on the church, Lumen Gentium, of the Second Vatican Council teaches the universal plan of God for all the people. The Council brings out the universality of the new people of God in two ways. First it points out that the Church takes its citizens from every race (LG 13). Secondly, the Council insists on the link that exists between the Church and 
International Journal of Arts and Humanities

ISSN: 2581-3102

Volume: 04, Issue: 04 "April 2020"

the rest of the humankind (LG 13). It was convinced that God's plan of salvation is absolutely universal (LG 2, 7, 12, ) and that the presence of Jesus is present and active in the whole world, directing the course of human history and imparting his saving grace both to Christians and nonChristians. In this sense, Vatican II regarded the whole humanity as the People of God. LG 13 clearly states that in general way all are called to belong to this "People of God." It is an all inclusive community (in different ways). The one People of God is present in all nations of the earth, since its citizens, who are taken from all nations, are of a kingdom whose nature is not earthly but heavenly. LG 14-17 also speak how does all the people belong to the community of people of God.

We see a parallel thought in Indian religious mind also. George Soares-Prabhu (1999b, 286) rightly quotes Krishna's reassurance in the Bhagavat Gita, a Hindu Religious text, that "Even those who lovingly devote themselves to other gods and sacrifice to them filled with faith, they really worship me, though the rite may differ from the norm" (9.23). Therefore, Is 44:9-20 could be better explained, in India, with the message of universalism of God's saving plan that allows and announces the salvation to all nations.

\subsection{Recognition of a Life Affirming God}

The exodus and exile stories in the Bible define the collective identity and ethnic boundaries of the people, and provides a common foundation for social and religious life, and one key dictum given to the people that provided for an authentic identity amidst the pluralistic ethos of the time, was the expectation on the part of Yahweh, that He would be the God of Israel and Israel would have no other god before Him (Melanchthon 2002). This command, in fact, asserts that there is an unbridgeable gulf between the worship of Yahweh and all other religions, which involve the worship of "other" gods. Nevertheless, we understand now that "the original cult-polemic progressed more and more into a form of theological evaluation, which regarded all visual symbolism as illicit and objectionable. In the later Jewish view, all images were gods "made with human hands"; this was the result of the understanding of God as transcendent and incorporeal" (Melanchthon 2002, 518).

But, in Indian context, we see always the personal and life affirming God experience. Here, all life is dependent upon God and that the world cannot find the meaning of its own life without first recognizing the source of all life. Therefore, Is 44:9-20 could be best explained as a discourse about the life affirming God in Indian context. Yet, it cannot be neglected that "there are other human discourses, at times endorsed in the name of God and religion, which serve enslaving and life threatening purposes. The caste system, racism, capitalism and patriarchy are human discourses that make possible oppression and enslavement because human being believe in such discourses and the elite find them helpful in preserving the status quo and in facilitating 
International Journal of Arts and Humanities

ISSN: 2581-3102

Volume: 04, Issue: 04 "April 2020"

their continued enjoyment of special privileges at the cost of the majority (Melanchthon 2002). Finally, this life affirming God calls people to abandon life destroying gods and give away the allegiance to something that annihilate life. In short, all enslaving and oppressing powers should be dethroned. Thus, this passage could be seen and interpreted particularly in Indian context as a protest against reducing God to the level of the particular, (particular race, religion, caste, gender or ethnicity), and elevating the particular to the level of God (Melanchthon 2002).

\subsection{A Medium for Establishing Communion with God}

People in India, particularly Hindus, view God as having both transcendental and immanent aspects. God, who exists in the spiritual abode (transcendence), is also present in the hearts of all individuals and at the core of the nature (immanence), and this immanent God descends into our world through different incarnations (avatars) and in the form of the Deities (Murti) (Tawfike 2011). Hence, the manifestation of God in "material" images along with incarnations is very comprehensible for the Indian mind. Therefore, these material images, as we call it as idols, are the medium for establishing communion with God. They are not the idle fancies of sculptors, but shining channel through which the heart of the devotee is attracted to and flows towards God. Though the image is worshipped, the devotee feels the presence of the Lord in it and pours out his devotion unto it (Sivananda 1993).

Therefore, there are also Hindus who see the divine images as merely a means to an end, a visible symbol leading to the "real" divinity, who is unmanifest. For those, the idol is a support for the neophyte. It is a support of his or her spiritual Child hood (Sivananda 1999). For, it is difficult to behold God everywhere and to see His presence without some mental imagination which we trace with some material reality tangible to us. Thus, this passage can be explained in India with a movement from immature religiosity where idols are confused with realities they represent and worship them, to a religious maturity where idols themselves are not seen as deities but representing only a larger reality which is the Absolute. In this respect, Catechism of the Catholic Church (CCC) no. 2113 also states that, "Idolatry not only refers to false pagan worship. It remains a constant temptation to faith. Idolatry consists in divinizing what is not God. Man commits idolatry whenever he honours and reveres a creature in place of God, whether this be gods or demons (for example, Satanism), power, pleasure, race, ancestors, the state, money, etc." (CCC 2113). Hence, finally, worshiping any material objects or other tangible images which are not seen as a vehicle to establish communion with the Absolute, becomes contrary to His Will.

\section{CONCLUSION}


International Journal of Arts and Humanities

ISSN: 2581-3102

Volume: 04, Issue: 04 "April 2020"

It is normally absurd to think that something we can make could actually deliver us form problems we could not free ourselves from. Therefore, generally, those who worship idols are said to be spiritually blind. However, in a society, where cultural and religious traditions and practices are more cosmocentric, and always look for something tangible and material to depend upon, the explanation that we give should be very mindful of this particular context. In the words of George Soares-Prabhu, "the proper locus for an Indian interpretation of the kind I have described, one which will respect both the Indian situation and the Indian mind, is not then, the seminary but the basic community - that is a pluri-religious group of people, living by basic human (and therefore gospel) values, and striving for the transformation of Indian society in the light of these" (Soares-Prabhu 1999a, 11). In this regard, Raimundo Panikkar explains that there is no 'lingua universalis', and thus, each tradition are understandable only within its proper background, and any pretension to universality is itself particular (Panikkar 1989). Many philosophers like Descartes and Leibniz argued for the existence of a 'lingua universalis' universal language - underlying all speech and that such a language represented the form of human reason (Canfield 2004). Raimundo Panikkar, on the contrary speaks about the contextual meaning of the language.

I conclude this study quoting Brahmabandab Upadhyay, a great Indian Christian thinker, who writes that: "The development of the Christian religion has not come to an end. It will grow, blossom and fructify till the end of time. Indian soil is humid and its humidity will make the ever-new Christian Revelation put forth newer harmonies and newer beauties, revealing more clearly the invisible integrity of the universal faith deposited in the Church by the Apostle of Jesus Christ. The Hindu mind and heart, coming under the domination of the One, Holy, Apostolic, and Catholic Church, will sing a new canticle which will fill the earth with sweetness from end to end" (Animananda 1946, 68).

Nevertheless, the alienation of an Indian interpreter from the Indian situation and the Indian mind will cause for a defective interpretation as far as the Indian social, cultural, and religious scenarios are concerned, and that will risk, in many ways, the grass-root communities to come to Jesus and his message of love that is proclaimed for all. Therefore, Indian reading basically involves both a reading that is True to the Text and a reading that is sensitive to the context.

\section{REFERENCES}

Animananda, Bhattacharya R. The Blade: Life and Work of Brhmabandab Uapadhyay. Calcutta: Roy and Sons, 1946.

Canfield, John V., ed. Philosophy of Meaning, Knowledge and Value in the Twentieth Century. Cornwall: Routledge, 2004. 
International Journal of Arts and Humanities

ISSN: 2581-3102

Volume: 04, Issue: 04 "April 2020"

D'Sa, Francis X., ed. Theology of Liberation: An Indian Biblical Perspective. Collected Writings of George M. Soares-Prabhu, vol. 4. Pune: Jnana-Deepa Vidyapeeth, 1999.

Dobie, Ann B. Theory into Practice: An Introduction to Literary Criticism, $3^{\text {rd }}$ ed. Boston, MA: Wadsworth, 2002.

Eck, D.L. Darsan: Seeing the Divine Image in India, $2^{\text {nd }}$ ed. Chambersburg: Anima Books, 1985.

Fiorenza, E. Schüssler. "The Ethics of Biblical Interpretation: Decentring Biblical Scholarship." Journal of Biblical Literature 107 (1988): 3-17.

http://www.vatican.va/archive/ENG0015/_P7E.HTM [accessed November 28 2019].

http://www.vatican.va/archive/hist_councils/ii_vatican_council/documents/vat-

ii_cons_19651207_gaudium-et-spes_en.html [accessed November 15 2013].

http://www.vatican.va/archive/hist_councils/ii_vatican_council/documents/vat-

ii_const_19641121_lumen-gentium_en.html [accessed November 25 2013].

https://bible.org/seriespage/dead-idols-or-living-god-isaiah-446-23 [accessed November 12 2019].

Kuthirakkattel, Scaria., ed. A Biblical Theology for India. Collected Writings of George M. Soares-Prabhu, vol. 2. Pune: Jnana-Deepa Vidyapeeth, 1999.

Kuthirakkattel, Scaria., ed. Biblical Spirituality of Liberative Action. Collected Writings of George M. Soares-Prabhu, vol. 3. Pune: Jnana-Deepa Vidyapeeth, 1999.

Land, Bernhard. Monotheism and the Prophetic Minority: An Essay in Biblical History and Sociology. Sheffield: Almond Press, 1983.

Melanchthon, Monica J. "I am the Lord Your God and You Shall Have no Other Gods before Me": Identity and Plurality." International Review of Mission 91, no. 363 (2002): 516522.

Padinjarekuttu, Isaac., ed. Biblical Themes for a Contextual Theology Today. Collected Writings of George M. Soares-Prabhu, vol. 1. Pune: Jnana-Deepa Vidyapeeth, 1999.

Panikkar, Raimundo. "The Crux of Christian Ecumenism: Can Universality and Chosenness be Held Simultaneously?” Journal of Ecumenical Studies 26, no.1 (1989): 82-99.

Panikkar, Raimundo. The Trinity and the Religious Experience of Man. Maryknoll, NY: Orbis Books, 1973. 
International Journal of Arts and Humanities

ISSN: 2581-3102

Volume: 04, Issue: 04 "April 2020"

Ricoeur, Paul. Interpretation Theory: Discourse and the Surplus of Meaning. Texas: Fort Worth, 1976.

Romus, John. "Karma and Bhakti Ways of Salvation: Christological Perspective." Indian Journal of Theology 37, no. 1 (1995): 1-14.

Sivananda, Sri Swami. All about Hinduism. Uttar Pradesh: The Divine Life Trust Society, 1999.

Sivananda, Sri Swami. The Philosophy and Significance of Idol Worship. Uttar Pradesh: The Divine Life Society, 1993.

Soares-Prabhu, George M. "From Alienation to Inculturation: Some Reflections on Doing Theology in India Today." In T. K. John, ed. Bread and Breath: Essays in Honour of Samuel Rayan. Anand: Gujarat Sahitya Prakash, 1991.

Soares-Prabhu, George M. "Interpreting the Bible in India Today." In Theology of Liberation: An Indian Biblical Perspective, vol. 4, ed. Francis X. D'Sa. Pune: Jnana-Deepa Vidyapeeth, 1999a.

Soares-Prabhu, George M. "Laughing at Idols: The Dark Side of Biblical Monotheism (An Indian Reading of Isaiah 44:9-20)." In A Biblical Theology for India: Collected Writings of George M. Soares-Prabhu, vol. 2, ed. Scaria Kuthirakkattel. Pune: Jnana-Deepa Vidyapeeth, 1999b.

Tawfike, Mina Fouad. "The Philosophy and Significance of Idol-Worship in Hinduism." (2011), 4. See, http://www.academia.edu/1768096/The_Philosophy_and_Significance_of_IdolWorship_in_Hinduism\# [accessed November 25 2019]. 